M.V. Bondarenko ${ }^{1}$, T.A. Khalyavka ${ }^{1}$, S.V. Camyshan ${ }^{1}$, I.S. Petrik ${ }^{2}$

\title{
PREPARATION AND CHARACTERIZATION OF TITANIUM DIOXIDE MODIFIED WITH CARBON WITH ENHANCED PHOTOCATALYTIC ACTIVITY
}

\author{
${ }^{1}$ Institute for Sorption and Problems of Endoecology of National Academy of Sciences of Ukraine \\ 13 General Naumov Str., Kyiv, 03164,Ukraine,E-mail: bondarenko_maryna@ukr.net \\ ${ }^{2}$ Chuiko Institute of Surface Chemistry of National Academy of Sciences of Ukraine \\ 17 General Naumov Str., Kyiv, 03164, Ukraine
}

The aim of our work was to prepare nanoscale composites based on $\mathrm{TiO}_{2}$ and carbon photocatalytically active under UV and visible irradiation in the destruction of safranin T. The samples were characterized by XRD, BET, SEM, $U V$-Vis and IR spectroscopy. X-ray analysis revealed photocatalytically active phase of anatase in all the composites. The powders consist of roundish agglomerates, crystallite size in agglomerates is $15 \mathrm{~nm}$. Analysis of nitrogen sorptiondesorption isotherms for the samples show the presence of a hysteresis loop which is the evidence for mesoporous structure.

Vibrational spectra of the composites reveal the following bands: near $700 \mathrm{~cm}^{-1}$ corresponding to the Ti-O stretching vibration; around $3407 \mathrm{~cm}^{-1}$ attributed to the surface-adsorbed $\mathrm{H}_{2} \mathrm{O}$; at $1628 \mathrm{~cm}^{-1}$ which is referred to deformational vibrations in adsorbed water, and around 1300-1500 $\mathrm{cm}^{-1}$ corresponding to carbon-oxygen bonds.

Absorption spectra of nanocomposites show a bathochromic shift as compared with those of TiO ${ }_{2}$. Modification of $\mathrm{TiO}_{2}$ with carbon leads to band gap narrowing of composites, as well as to emerging of additional energy levels in the band gap of $\mathrm{TiO}_{2}$ with energies of 3.12-3.14 eV under valence band; that leads to sensitizing of $\mathrm{C} / \mathrm{TiO}_{2}$ composites to visible irradiation. Nanocomposites show higher photocatalytic activity compared to pure $\mathrm{TiO}_{2}$. It may be connected with the participation of carbon in the inhibition of electron-hole recombination, prolongation of charge lifetime, increasing of efficiency of interfacial charge separation from $\mathrm{TiO}_{2}$ to carbon and formation of doping electronic states inside the TiO band gap.

Keywords: titanium dioxide, carbon, safranin $T$, photocatalysis

\section{INTRODUCTION}

Photocatalysis has proven to be a promising technique for the degradation of hazardous compounds in aqueous solutions. Titanium dioxide is the widely used photocatalyst for water purification, however, it has several serious disadvantages: the low quantum yield of the reaction, wide band gap $(3.2 \mathrm{eV})$, high rate of electron-hole recombination, and peculiarity of light adsorption by $\mathrm{TiO}_{2}$ resulting in its photochemical activity only in the UV region of spectrum. But ultraviolet light occupies only $4 \%$ of sunlight; on the other hand, visible light accounts about $43 \%$. Thus, it seems more practical and favorable to use visible light rather than ultraviolet light for the degradation of water pollutions. So, an urgent problem in photocatalysis is a search for photocatalytic systems active under visible light irradiation which gives an opportunity of their widespread practical application.

Researchers are trying to shift the optical sensitivity of $\mathrm{TiO}_{2}$ from UV to the visible-light region by many methods, such as metal loading, doping and coupling of composite semiconductors. Nanocomposites composed of $\mathrm{TiO}_{2}$ and carbon materials (C) are widely popular photocatalysts because they combine the advantages of $\mathrm{TiO}_{2}$ (good UV photocatalytic activity, low cost, and stability) to the enhanced charge carrier separation and lower charge transfer resistance brought by carbon. Many different $\mathrm{C} / \mathrm{TiO}_{2}$ photocatalysts have been studied, including $\mathrm{C}$-doped $\mathrm{TiO}_{2}, \mathrm{TiO}_{2}$ supported on carbon materials, carbon nanostructures embedded in $\mathrm{TiO}_{2}$ and $\mathrm{C}$-coated $\mathrm{TiO}_{2}[1-6]$.

So, the aim of our work was to prepare the samples of carbon/ $/ \mathrm{TiO}_{2}$ by an economical pathway and to test them under UV and visible light irradiation. We chose cationic dye safranin $\mathrm{T}(S T)$ as the model of pollutants to evaluate the degradation activity of composites.

\section{EXPERIMENTAL}

Preparation of composites. The samples of titanium dioxide modified with carbon were 
obtained through calcination of mixtures of titanium(IV) tetrabutoxide (Aldrich), citric acid, glycerol [7], and different samples of carbon: $\mathrm{C} 1$ $(0.05,0.07,1$ and $1.3 \mathrm{~g})$ and $\mathrm{C} 2(0.05,0.07,1$ and $1.3 \mathrm{~g})$. The carbon samples were obtained according to technique developed in this laboratory and have different textural characteristics (Table 1). So, the samples designated as $1 \mathrm{C} 1 / \mathrm{TiO}_{2}, 2 \mathrm{C} 1 / \mathrm{TiO}_{2}$, $3 \mathrm{C} 1 / \mathrm{TiO}_{2}, 4 \mathrm{C} 1 / \mathrm{TiO}_{2}$ and $1 \mathrm{C} 2 / \mathrm{TiO}_{2}, 2 \mathrm{C} 2 / \mathrm{TiO}_{2}$, $3 \mathrm{C} 2 / \mathrm{TiO}_{2}, 4 \mathrm{C} 2 / \mathrm{TiO}_{2}$, respectively. The powders were prepared at stepwise heating $(200,300,400$ and $500{ }^{\circ} \mathrm{C}$ ) in the presence of air oxygen. Before annealing, mixture was carefully stirred up to yield uniform mass. For pure titanium dioxide, the same mixture was used, but without addition of activated carbon.

Characterization of photocatalysts. To analyze samples morphology a scanning electron microscope (SEM JSM 6490 LV, JEOL, Japan) was used.

$\mathrm{X}$-ray phase analysis was performed using a diffractometer Dron-4-07 (Russia) at $\mathrm{Cu} K_{\alpha}$ radiation (with copper anode and nickel filter) in reflection beam and the Bragg-Brentano registration geometry $\left(2 \theta=10-70^{\circ}\right)$. Average crystallite size was determined using broadening of the most intensive band by means of the DebyeScherrer equation [8]: $D=0.9 \lambda / B \cos \theta$, where 0.9 is a constant, $\lambda$ is a wavelength, $\mathrm{nm}$. Crystalline sizes were determined through characteristics of the most intensive peaks. Interplanar distance $(d, \mathrm{~nm})$ was calculated using Wulff-Bragg's equation: $n \lambda=2 d \sin \theta$, where $n=1$ is the order of reflection, $\lambda=0.154 \mathrm{~nm}$ is the wavelength, $\theta$ is the scattering angle, degrees. Thereby, $d=n \lambda / 2 \sin \theta$.

The values of specific surface area $\left(S_{\mathrm{sp}}\right)$ of the samples as well as distribution of pores by volume were determined using a Quantachrom NovaWin2 device. The specific surface of the samples was obtained from the isotherms of nitrogen sorptiondesorption using the Brunauer-Emmet-Teller (BET) approach [9]. The pore radius $(R)$ and the pore volume $\left(V_{\text {tot }}\right)$ were calculated from the desorption branches of the isotherms using the Barret-Joiner-Halenda method [10].

Optical spectra of powders were measured using a Perkin-Elmer Lambda Bio 35 spectrophotometer in the range between 200 and $1000 \mathrm{~nm}$ which allows one to convert data of corresponding spectra by the help of the KubelkaMunk equation.
IR spectra of the powders were registered using a single-ray FT IR spectrometer Thermo Nicolet Nexus FT-IR (Germany) in the region 500 to $4000 \mathrm{~cm}^{-1}$. Synthesized samples under study were mixed with freshly calcined $\mathrm{KBr}$ in 1:4 ratio.

Photocatalytical experiment. Photocatalytic activity of the samples was evaluated by rate constants of destruction $\left(k_{\mathrm{d}}\right)$ of cationic dye ST $(C=0.03 \mathrm{~g} / \mathrm{l})$. Before irradiation, catalyst suspension in aqueous substrate solution was left in dark up to achieve adsorption equilibrium. In order to determine the optimal quantity of photocatalyst in the reactions under study, its concentration was increased at the constant substrate concentration. The dependence of safranin destruction rate constant $\left(k_{\mathrm{d}}\right)$ on the catalyst concentration shows that at low dye concentrations $(\leq 2 \mathrm{~g} / \mathrm{l})$ an increase of the safranin destruction rate constant with the increase of photocatalyst amount in the reaction millieu is observed while it achieves a plateau consequently when photocatalyst concentration approaches roughly $2 \mathrm{~g} / \mathrm{l}$. All the rest photocatalytic reactions were carried out at the photocatalyst concentration equal to $2 \mathrm{~g} / \mathrm{l}$. Analagous dependences were obtained in the works $[11,12]$.

Irradiation of aqueous solutions ( $\mathrm{pH}$ 6.5) of dye was performed at room temperature in quartz reactor in the presence of air oxygen. The light source was a high-intensity $\mathrm{Na}$ discharge lamp GE Lucalox (Hungary) with power of $70 \mathrm{~W}$, the latter emitting in the visible region with maxima at 568, 590, and $600 \mathrm{~nm}$ and an UV lamp BUV-30 (Russia) with the power of $30 \mathrm{~W}$ and radiation maximum at $254 \mathrm{~nm}$.

Concentrations of the substrate were measured spectrophometrically using a Shimadzu UV-2450 spectrophotometer at $\lambda=520 \mathrm{~nm}$ for ST. Photocatalytic rate constants for the model compound were calculated using the first order kinetic equation.

\section{RESULTS AND DISCUSSION}

Analysis of SEM-images of the samples shows that they consist of roundish agglomerates (Fig. $1 a$ ). Diffractograms of all powders show intensive peaks which belong to anatase phase (Fig. $1 \mathrm{~b}$ ) as in works $[1,3,4]$. No signal of brookite or rutile is detected by XRD. So, insertion of carbon into the binary composites does not induce new crystalline forms different from anatase. The peaks are quite broad, indicating small 
crystallite sizes. Crystallite size in agglomerates of samples as calculated through Debye-Scherrer equation equals to $15 \mathrm{~nm}$.

The samples show the presence of a hysteresis loop which is the evidence for mesoporous structure of the powders (Fig. $2 a$ ). The isotherms correspond to type IV of IUPAC classification for mesoporous materials with $\mathrm{H} 1$ type of hysteresis loop.

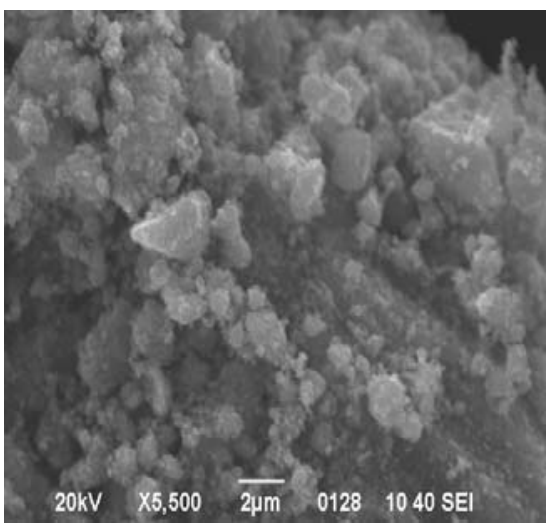

$a$
Predominance of pores up to $35 \mathrm{~nm}$ is characteristic of pure titanium dioxide, whereas for composite samples this value is of 5-35 nm (Fig. $2 b$ ).

The texture characteristics of the samples are presented in Table 1. Compared with titanium dioxide, specific surface of binary system $\mathrm{C} / \mathrm{TiO}_{2}$ samples decreases with $\mathrm{C} 1$ addition and increases with $\mathrm{C} 2(\geq 0.07 \mathrm{~g})$ addition, pore volume and radius decreasing.

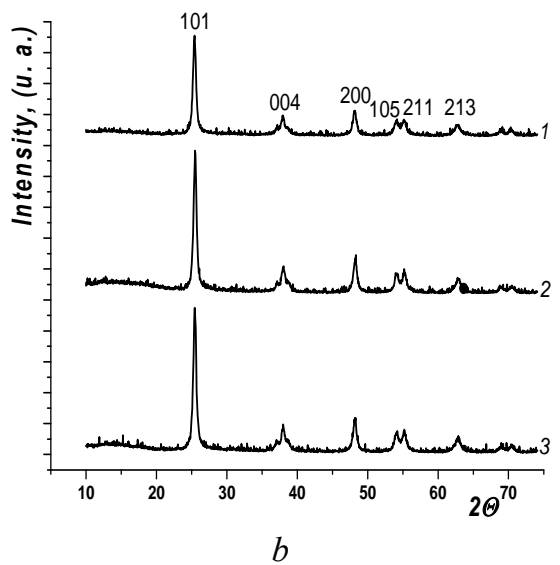

Fig. 1. SEM-image of the $1 \mathrm{C} 1 / \mathrm{TiO}_{2}$ sample $(a)$ and $\mathrm{XRD}$ patterns $(b)$ for: $1-\mathrm{TiO}_{2}, 2-3 \mathrm{C} 2 / \mathrm{TiO}_{2}, 3-3 \mathrm{C} 1 / \mathrm{TiO}_{2}$

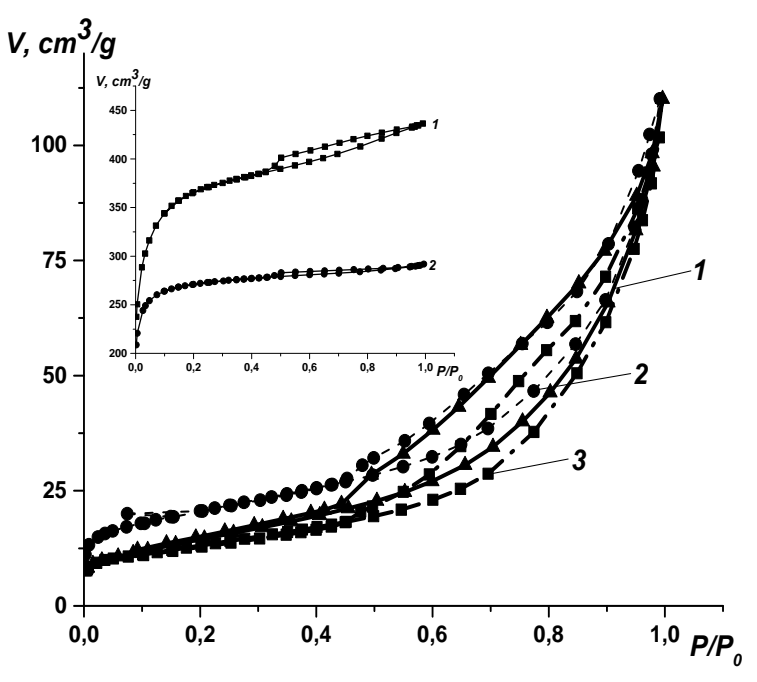

$a$

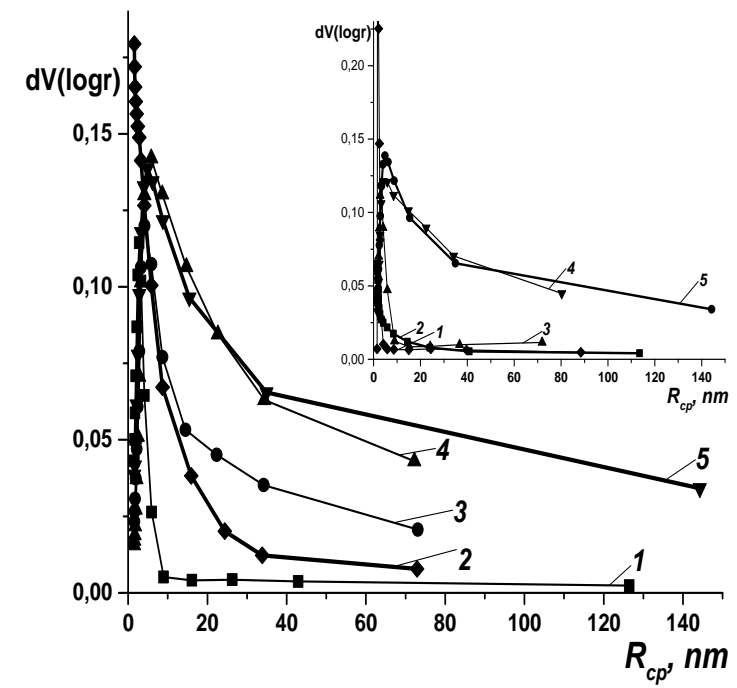

$b$

Fig. 2. Isotherms of nitrogen sorption-desorption obtained at $20{ }^{\circ} \mathrm{C}$ for the studied samples $(a): 1-\mathrm{TiO}_{2}, 2-4 \mathrm{C} 2 / \mathrm{TiO}_{2}$, $3-4 \mathrm{C} 1 / \mathrm{TiO}_{2}$ (insets: $\left.1-\mathrm{C} 1,2-\mathrm{C} 2\right)$ and pore size distribution for the samples $(b): 1-2 \mathrm{C} 1 / \mathrm{TiO}_{2}, 2-\mathrm{C} 1,3-$ $3 \mathrm{Cl} / \mathrm{TiO}_{2}, 4-4 \mathrm{Cl} / \mathrm{TiO}_{2}, 5-\mathrm{TiO}_{2}$ (insets: $1-3 \mathrm{C} 2 / \mathrm{TiO}_{2}, 2-2 \mathrm{C} 2,3-2 \mathrm{C} 2 / \mathrm{TiO}_{2}, 4-4 \mathrm{C} 2 / \mathrm{TiO}_{2}, 5-\mathrm{TiO}_{2}$ )

The functional groups of the $\mathrm{TiO}_{2}$ and $\mathrm{C} / \mathrm{TiO}_{2}$ materials were characterized by FTIR transmittance, as shown in Fig. 3.

The band near $700 \mathrm{~cm}^{-1}$ corresponds to the Ti-O stretching vibration, and is present in all samples. The broad band around $3407 \mathrm{~cm}^{-1}$ attributed to the surface-adsorbed $\mathrm{H}_{2} \mathrm{O}$ and the absorption band at $1628 \mathrm{~cm}^{-1}$ refers to deformational vibrations in adsorbed water [13]. Broad band around $3407 \mathrm{~cm}^{-1}$ remains in spectra of modified samples, but the band at $1628 \mathrm{~cm}^{-1}$ almost vanishes and intensive peaks in the region 
of $1300-1500 \mathrm{~cm}^{-1}$ appear. They correspond to carbon-oxygen bonds [14].

Absorption spectra of nanocomposites (Fig. 4) show a bathochromic shift as compared to the absorption band of pure $\mathrm{TiO}_{2}$. The UV-Vis spectra reveal that the pure $\mathrm{TiO}_{2}$ exhibit an absorption edge around $380 \mathrm{~nm}$, the composite samples extended the absorption to the visible range (around $420 \mathrm{~nm}$ ). This may indicate that carbon and $\mathrm{TiO}_{2}$ nanoparticles are integrated to form $\mathrm{C} / \mathrm{TiO}_{2}$ nanocomposites [4].

Table 1. Structural characteristics of the samples

\begin{tabular}{cccc}
\hline Sample & $\boldsymbol{S}_{\mathbf{s p}}, \mathbf{m}^{\mathbf{2}} / \mathbf{g}$ & $\boldsymbol{V}_{\text {tot }} \mathbf{\mathbf { ~ m } ^ { 3 }} / \mathbf{g}$ & $\boldsymbol{R}, \mathbf{n m}$ \\
\hline $\mathrm{C} 1$ & 1386.0 & 0.68 & 9.8 \\
$\mathrm{C} 2$ & 1064.0 & 0.45 & 8.5 \\
$\mathrm{TiO}_{2}$ & 53.2 & 0.17 & 6.4 \\
$1 \mathrm{C} 1 / \mathrm{TiO}_{2}$ & 34.8 & 0.06 & 3.6 \\
$2 \mathrm{C} / \mathrm{TiO}_{2}$ & 51.9 & 0.06 & 2.3 \\
$3 \mathrm{C} 1 / \mathrm{TiO}_{2}$ & 43.3 & 0.11 & 5.1 \\
$4 \mathrm{C} 1 / \mathrm{TiO}_{2}$ & 47.2 & 0.16 & 6.7 \\
$1 \mathrm{C} 2 / \mathrm{TiO}_{2}$ & 35.5 & 0.09 & 5.5 \\
$2 \mathrm{C} / \mathrm{TiO}_{2}$ & 77.5 & 0.08 & 2.1 \\
$3 \mathrm{C} 2 / \mathrm{TiO}_{2}$ & 55.1 & 0.07 & 2.5 \\
$4 \mathrm{C} 2 / \mathrm{TiO}_{2}$ & 73.5 & 0.17 & 4.6 \\
\hline
\end{tabular}

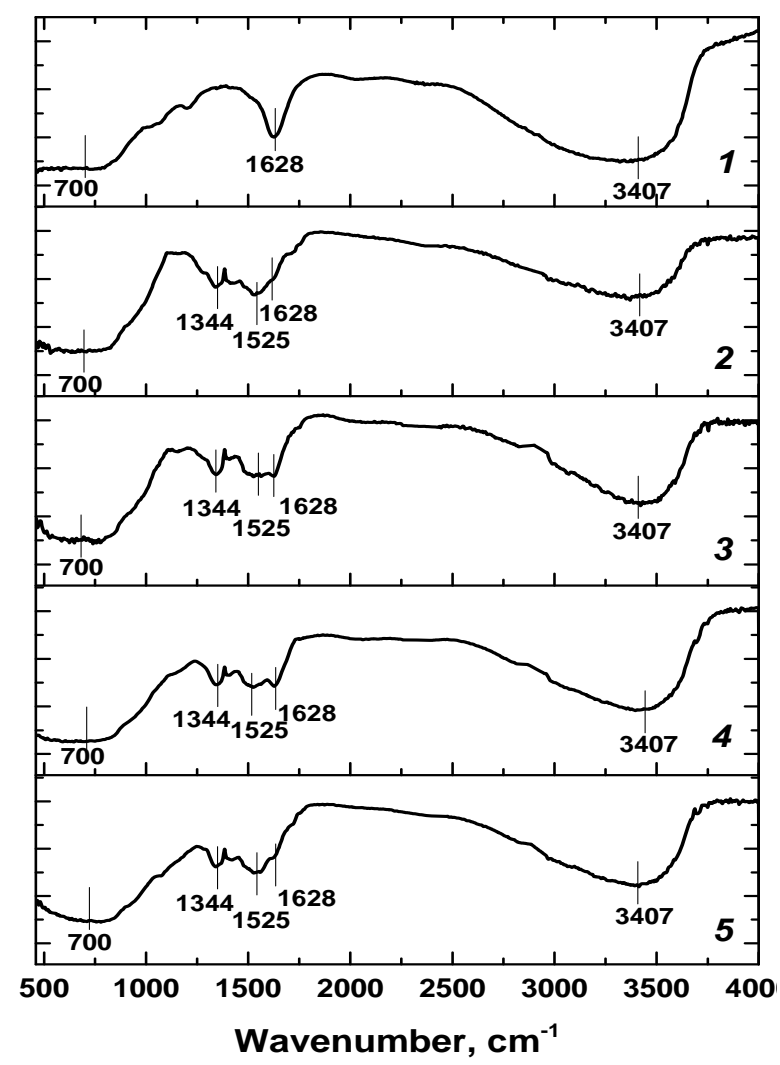

Fig. 3. IR spectra of: $1-\mathrm{TiO}_{2}, 2-4 \mathrm{C} 2 / \mathrm{TiO}_{2}, 3-2 \mathrm{C} 2 / \mathrm{TiO}_{2}, 4-4 \mathrm{C} 1 / \mathrm{TiO}_{2}, 5-2 \mathrm{C} 1 / \mathrm{TiO}_{2}$ 

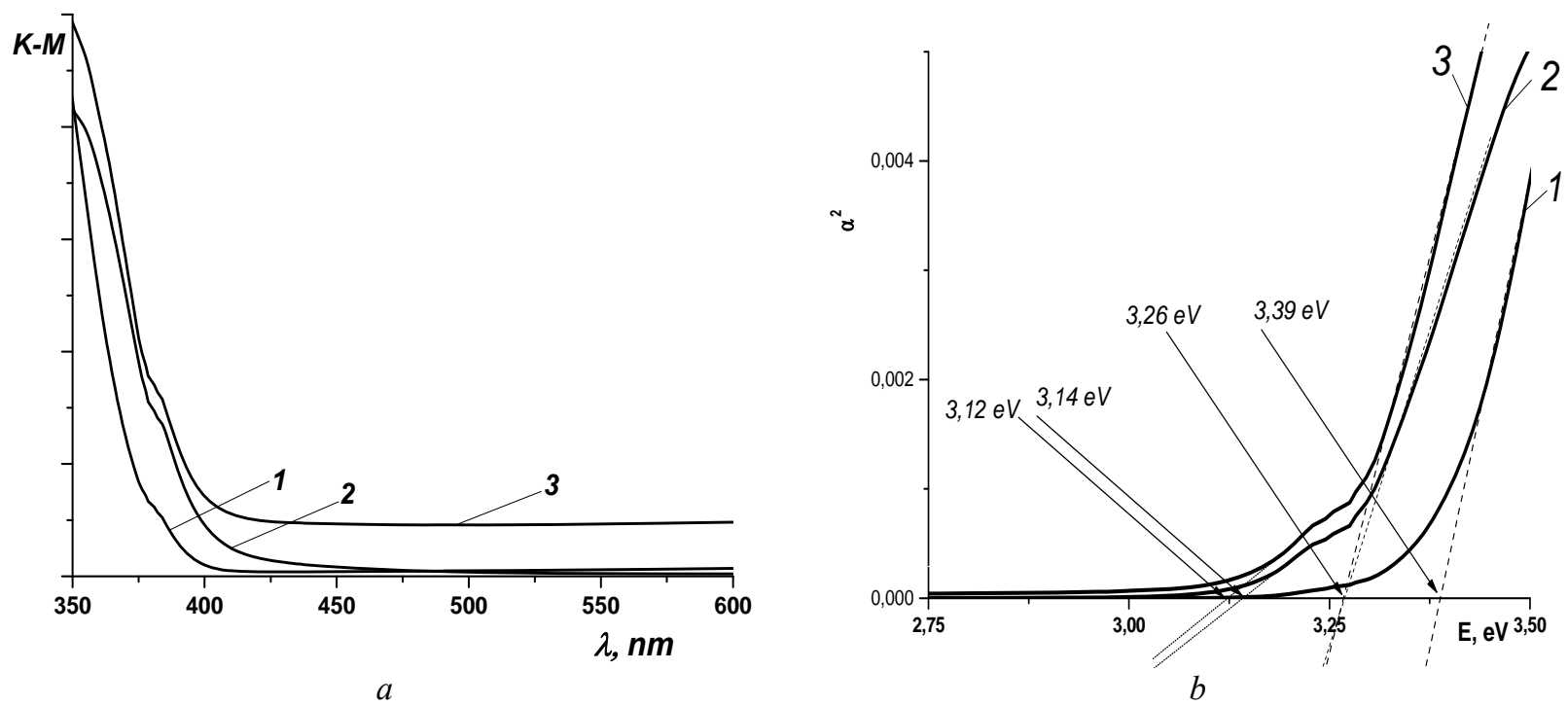

Fig. 4. $a$ : UV-Vis diffuse reflectance spectra of samples: $1-\mathrm{TiO}_{2}, 2-2 \mathrm{C} 2 / \mathrm{TiO}_{2}, 3-3 \mathrm{C} 2 / \mathrm{TiO}_{2}$; $b$ : Square of extinction coefficient as dependent of incident irradiation energy for powders: $1-\mathrm{TiO}_{2}, 2-2 \mathrm{C} 2 / \mathrm{TiO}_{2}, 3-3 \mathrm{C} 2 / \mathrm{TiO}_{2}$

Modification of titanium with carbon leads to band gap narrowing of composites (Fig. 4 b), as well as to emerging of additional energy levels in the band gap of $\mathrm{TiO}_{2}$ with energies of $3.12-3.14 \mathrm{eV}$ under valence band; that leads to sensitizing of $\mathrm{C} / \mathrm{TiO}_{2}$ composites to irradiation in the visible region of spectrum.

The photocatalytic activity of all the materials was tested for the decomposition of safranin $\mathrm{T}$ in aqueous solution. Previous to irradiation, photocatalyst-dye systems were kept in the dark to achieve sorption equilibrium for $24 \mathrm{~h}$. Irradiation of dye solution in water in the presence of photocatalyst leads to a decrease in dye concentration in solution, process rate depending on photocatalyst composition (Table 2). Thus, rate of catalytic destruction of dye at UV irradiation in presence of titanium dioxide powder increases more than by a factor of ten (Table 2).

Table 2. Photocatalytic activity of investigated samples in the destruction of safranin $\mathrm{T}$

\begin{tabular}{ccc}
\hline Sample & $\mathbf{U V ~}\left(\boldsymbol{k}_{\boldsymbol{d}} \times \mathbf{1 0}^{\mathbf{- 4}}, \mathbf{s}^{\mathbf{- 1}}\right)$ & $\mathbf{V i s}\left(\boldsymbol{k}_{\boldsymbol{d}} \times \mathbf{1 0}^{-\mathbf{4}}, \mathbf{s}^{\mathbf{- 1}}\right)$ \\
\cline { 2 - 3 } & & $\mathbf{S F}$ \\
\hline- & 0.2 & - \\
$\mathrm{TiO}_{2}$ & 2.9 & - \\
$1 \mathrm{C} 1 / \mathrm{TiO}_{2}$ & 3.9 & 0.3 \\
$2 \mathrm{C} 1 / \mathrm{TiO}_{2}$ & 7.7 & 0.4 \\
$3 \mathrm{C} 1 / \mathrm{TiO}_{2}$ & 4.9 & 0.4 \\
$4 \mathrm{C} 1 / \mathrm{TiO}_{2}$ & 2.5 & 0.2 \\
$1 \mathrm{C} 2 / \mathrm{TiO}_{2}$ & 3.7 & 0.9 \\
$2 \mathrm{C} 2 / \mathrm{TiO}_{2}$ & 5.8 & 1.1 \\
$3 \mathrm{C} 2 / \mathrm{TiO}_{2}$ & 4.5 & 0.8 \\
$4 \mathrm{C} 2 / \mathrm{TiO}_{2}$ & 2.8 & 0.8 \\
\hline
\end{tabular}

$\mathrm{C} / \mathrm{TiO}_{2}$ samples manifested a higher photocatalytic activity as compared to that of pure titanium dioxide at UV irradiation (Table 2). According to [15], the effect of carbon content is different for different pollutants or different light sources. In our case, the greatest activity was detected for the samples $2 \mathrm{C} 1 / \mathrm{TiO}_{2}$ and $2 \mathrm{C} 2 / \mathrm{TiO}_{2}$.
Enhancement of photocatalytic activity of the modified samples may be connected with the participation of carbon in the inhibition of electron-hole recombination and prolongation of lifetime of charges which take part of the destruction processes and with the increasing of efficiency of interfacial charge separation from 
$\mathrm{TiO}_{2}$ to carbon. The authors [4] suggested that partial charge transfer occurred from carbon nanoparticles to $\mathrm{TiO}_{2}$ by the interfacial $\mathrm{Ti}-\mathrm{O}-\mathrm{C}$ linkages and the electron-accepting sites on the carbon nanoparticles facilitate interfacial charge separation.

Dye in aqueous solution, as being exposed to visible light either without any catalyst, or in the presence of pure titanium oxide shows no concentration change. Composite samples were photocatalytically active in destruction of ST under visible light irradiation, in contrast with pure titanium dioxide which acts as a photocatalyst only under UV irradiation. The greatest activity was detected for $2 \mathrm{C} 2 / \mathrm{TiO}_{2}$ sample. According to the literature [16], carbon in the composites acts as a doping agent, and some $\mathrm{C}$-Ti bonds are formed.
The mechanism of the $\mathrm{C} / \mathrm{TiO}_{2}$ photocatalytic activity improvement under visible light can be explained by the formation of doping electronic states inside the $\mathrm{TiO}_{2}$ band gap [17]. In our case, addition of carbon narrows the band gap of the composites as compared to that of pure $\mathrm{TiO}_{2}$ $(3.39 \mathrm{eV})$; it also leads to emerging of additional energy levels in the band gap of $\mathrm{TiO}_{2}$ with energies of $3.12-3.14 \mathrm{eV}$ under valence band; that leads to sensitizing of $\mathrm{C} / \mathrm{TiO}_{2}$ composites to irradiation in visible region of spectrum; so it is possible to obtain photoactivity at visible irradiation.

Thus, composite materials proved to be perspective photocatalysts. They might be used in photocatalysis for industrial waste purification of various organic impurities, in particular, dyes that are stable in the environment.

\title{
Отримання та характеризація діоксиду титану, модифікованого вуглецем, 3 підвищеною фотокаталітичною активністю
}

\author{
М.В. Бондаренко, Т.О. Халявка, С.В. Камишан, І.С. Петрик \\ Інститут сорбиії та проблем ендоекологї Національної академії наук Украӥни \\ вул. Генерала Наумова, 13, Київ,03164, Україна, bondarenko_maryna@ukr.net \\ Інститут хімії поверхні ім. О.О. Чуйка Національної академії наук Украӥни \\ вул. Генерала Наумова, 17, Київ, 03164, Украӥна
}

\begin{abstract}
Одержано нанорозмірні композичійні матеріали на основі діоксиду титану $і$ вуглецю. Зразки характеризували методами РФА, БЕТ, СЕМ, УФ і видимої спектроскопії̈ та ІЧ-спектроскопї. За допомогою рентгенофазового аналізу в усіх композитах виявлено фотокаталітично активну фазу анатазу. Дослідження ізотерм сорбиї-десорбиії азоту для синтезованих зразків показало наявність петлі гістерезису, що свідчить про мезопорувату структуру порошків. Встановлено, щчо композити складаються з круглястих агломератів, розмір кристалітів в яких становить 15 нм. Нанокомпозитні зразки виявили підвищену фотокаталітичну активність в деструкиї органічного барвника сафраніну Т при УФ та видимому опроміненні в порівнянні з чистим діоксидом титану. Це може бути пов'язано з участю вуглецю в інгібуванні процесу рекомбінації електронів та дірок, подовженні життя зарядів, збільшенні ефективності міжфазового розділу зарядів на межі фаз $\mathrm{TiO}_{2}$ та вуглецюю, а також формуванні додаткових електронних рівнів.
\end{abstract}

Ключові слова: діоксид титану, вуглець, сафранін $T$, фотокаталіз

\section{Получение и характеризация диоксида титана, модифицированного углеродом, с повышенной фотокаталитической активностью}

\author{
М.В. Бондаренко, Т.А. Халявка, С.В. Камышан, И.С. Петрик
}

Институт сорбции и проблем эндоэкологии Национальной академии наук Украинь ул. Генерала Наумова, 13, Киев,03164, Украина, bondarenko_maryna@ukr.net

Институт химии поверхности им. А.А. Чуйко Наџиональной акадееми наук Украинь ул. Генерала Наумова, 17, Киев, 03164, Украина

\footnotetext{
Получены наноразмерные композиционные материаль на основе диоксида титана и углерода. Образцы характеризовали методами РФА, БЭТ, СЭМ, УФ и видимой спектроскопии, а также ИК-спектроскопии.
} 
Рентгенофазовый анализ показал наличие фотокаталитически активной фазы анатаза во всех композитах. Исследование изотерм сорбции-десорбции азота для синтезированных образцов показало наличие петли гистерезиса, что свидетельствует о мезопористой структуре порошков. Установлено, что композить состоят из округлых агломератов, размер кристаллитов в которых составляет 15 нм. Нанокомпозитные образиы проявили более высокую фотокаталитическую активность в деструкиии органического красителя сафранина Т при УФ и видимом облучении по сравнению с чистым диоксидом титана. Это может быть связано с участием углерода в ингибировании процесса рекомбинации электронов и дырок, продлении жизни зарядов, увеличении эффективности межфазового разделения зарядов на гранище фаз ТіО формировании дополнительных электронных уровней.

Ключевые слова: диоксид титана, углерод, сафранин Т, фотокатализ

\section{REFERENCES}

1. Wang Sh., Zhao L., Bai L., Yan J., Jiang Q., Lian J. Enhancing photocatalytic activity of disorder engineered $\mathrm{C} / \mathrm{TiO}_{2}$ and $\mathrm{TiO}_{2}$ nanoparticles. J. Mater. Chem. A. 2014. 2: 7439.

2. Xing B., Shi Ch., Zhang Ch., Yi G., Chen L., Guo H., Huang G., Cao J. Preparation of $\mathrm{TiO}_{2} /$ activated carbon composites for photocatalytic degradation of RhB under UV light irradiation. J. Nanomater. 2016. 2016: Article ID 8393648.

3. Ansón-Casaos A., Tacchini I., Unzue A., Martínez M. T. Combined modification of a $\mathrm{TiO}_{2}$ photocatalyst with two different carbon forms. Appl. Surf. Sci. 2013. 270: 675.

4. Lin C., Song Y., Cao L., Chen Sh. Effective photocatalysis of functional nanocomposites based on carbon and $\mathrm{TiO}_{2}$ nanoparticles. Nanoscale. 2013. 5: 4986.

5. Matos Ju., Miranda C., Poon P. S., Mansilla H. D. Nanostructured hybrid $\mathrm{TiO}_{2}$-C for the photocatalytic conversion of phenol. Sol. Energ. 2016. 134: 64.

6. Yan Y., Yu Y., Cao C., Huang Sh., Yang Y., Yang X., Cao Y. Enhanced photocatalytic activity of $\mathrm{TiO}_{2}-\mathrm{Cu} / \mathrm{C}$ with regulation and matching of energy levels by carbon and copper for photoreduction of $\mathrm{CO}_{2}$ into $\mathrm{CH}_{4}$. Cryst. Eng. Comm. 2016.18: 2956.

7. Khalyavka T.A., Kapinus E.I., Viktorova T.I., Tsyba N.N. Adsorption and photocatalytic properties of nanodimensional titanium-zinc oxide composites. Theor. Exp. Chem. 2009. 45(4): 234.

8. Guinier A. Théorie et technique de la radiocristallographie. (Paris: Dunot, 1956).

9. Brunauer S., Emmett P.H., Teller E. Adsorption of gases in multimolecular Layers. J. Am. Chem. Soc. 1938. 60(2): 309 .

10. Barret E.P., Joyner L.G., Halenda P.P. The determination of pore volume and area distributions in porous substances. I. Computations from nitrogen isotherms. J. Am. Chem. Soc. 1951. 73(3): 373.

11. Kapinus E.I., Viktorova T.I., Khalyavka T.A. Dependence of the rate of photocatalytic decomposition of safranine on the catalyst concentration. Theor. Exp. Chem. 2009. 45(2): 114.

12. Kapinus E.I., Viktorova T.I., Khalyavka T.A. The mechanism and kinetics of photocatalytic degradation of DDT on the oxide titanium catalysts. Ukr. Chem. J. 2009. 75(12): 102. [in Ukrainian].

13. Ding Z., Lu G.Q., Greenfield P.F. Role of the crystallite phase of $\mathrm{TiO}_{2}$ in heterogeneous photocatalysis for phenol oxidation in water. J. Phys. Chem. B. 2000. 104(19): 4815.

14. Cheng C.H., Lehmann J., Thies J.E., Burton S.D., Engelhard M.H. Oxidation of black carbon by biotic and abiotic processes. Org. Geochem. 2006. 37(11): 1477.

15. Li L., Yi Zh., Yuexiang Zh., Youchang X. Effect of carbon content on photocatalytic activity of $\mathrm{C} / \mathrm{TiO}_{2}$ composite. Front. Chem. Chin. 2007. 2(1): 64.

16. Dong F., Wang H., Wu Z. One step «green» synthetic approach for mesoporous C-doped titanium dioxide with efficient visible light photocatalytic activity. J. Phys. Chem. C. 2009. 113(38): 16717.

17. Leary R., Westwood A. Carbonaceous nanomaterials for the enhancement of $\mathrm{TiO}_{2}$ photocatalysis. Carbon. 2011. 49(3): 741. 